\title{
The routes of critical metaphysics: Valentin Kanawrow's contribution
}

\author{
Las rutas de la metafisica crítica: \\ la contribución de Valentin Kanawrow
}

\author{
CHRISTIAN ENCHEV \\ ISSK-BAS, Sofia, Bulgaria
}

Recibido: 06/06/2016 Aceptado: 16/06/2016

\begin{abstract}
:
The aim of the present text is to reflect on Kanawrow's Tetralogy as an original approach to Kantian critcal metaphysics with a view to achieving the greatest clarity level of theoretical philosophising in formal and conceptual sense. Special light will be thrown here on some logical aspects of the transition from intentionality to intensionality. Transcendental synthesis is explicated toroughtly as a generative mechanism towards initially independent objectness: the virtual topos of thinking needs an emphasis on its metaphysically clarified purity. In accordance with my own approach the transition from a priori to a posteriori should be clearly explicated as a transition from intentionality to intensionality - to regional (actual) human experience which falls in the range of presumed open valences of thinking. The newly considered virtualistic phenomenon is in use in accordance with transcendentalising of actual experience. In addition, logical functionality of thinking receives a cognitive significance against our actual experience. That guarantees a variety of successful routes of transcendental schematism in its virtualistic version (transcendental phenomenology).
\end{abstract}

\author{
KEYWORDS
}

CRITICAL METAPHYSIC, VIRTUALISTIC METAPHYSICS, VIRTUAL TOPOS OF THINKING, UNLOCKING, DEVIRTUALISATION, TRANSCENDENTAL SYNTHESIS.

(C) Contrastes. Revista Internacional de Filosofia, vol. XXI-N²2 (2016), pp. 163-169. ISSN: 1136-4076 Departamento de Filosofía, Universidad de Málaga, Facultad de Filosofía y Letras Campus de Teatinos, E-29071 Málaga (España) 


\section{RESUMEN}

El objetivo del presente texto es reflexionar sobre la tetralogía de Kanawrow como un enfoque original de la metafísica critica kantiana con el fin de alcanzar el mayor nivel de claridad de filosofar teórico en el sentido formal y conceptual. Se esclarecerán especialmente algunos aspectos lógicos de la transición de la intencionalidad hacia la intensionalidad. La síntesis trascendental se explica como un mecanismo generativo hacia la objetividad inicialmente independiente: el topos virtual de pensamiento necesita un énfasis en su pureza que es metafísicamente aclarada. De acuerdo con mi propio enfoque la transición de a priori a a posteriori debe estar claramente explicada como una transición de la intencionalidad a la intensionalidad - hacia la (real) experiencia regional humana que se encuentra en el rango de valencias abiertas presumidas del pensamiento. El considerado virtualistic phenomenon está en uso, de conformidad con transcendentalisacion de la experiencia actual. Además, la funcionalidad lógica del pensamiento recibe un significado cognitivo en contra de nuestra experiencia real. Estas consideraciones garantizan una variedad de rumbos exitosos del esquematismo trascendental en su versión virtualistica (fenomenología trascendental).

PALABRAS CLAVES

METAFÍSICA CRÍTICA, METAFÍSICA VIRTUAL, TOPOS VIRTUAL DE PENSAMIENTO, DE VIRTUALIZACIÓN

IN AUTUMN 2015, Valentin Kanawrow's book Routes of Transcendental Schematism was published as an essential systematic result and a conceptual upgrade of the following works that came before this endeavour of the same author: The Critical Metaphysics of Kant. An Attempt for Virtualistic Transcendentalism (2003), Critical Ontologems of Spirituality (2006); Routes of Metaphysics. Kant and Heidegger (2011).

The critical metaphysics of Valentin Kanawrow is an essential philosophical achievement, encompassing a 20-year long systematic work. As a non-conservative extension of Kantian transcendental philosophy, it crowns the attempt of the author to radically rethink and continue the theoretical direction of the second edition of The Critique of Pure Reason. In this way, according to the author, the philosophical critique receives the exceptional chance to be completely discerned and clarified of different possible forms and manifestations of psychologism, anthropologism and subjectivism; thus, this is a critical - in the essence of Kantian spirit - path to achieving the greatest clarity level of theoretical philosophizing in formal and conceptual sense.

The basic - and namely, transcendental in its character - line of Kanawrow's critical metaphysics is to sustain the direction from a priori to a posteriori as a strictly systematically conducted one-way transition. The way back is unacceptable: the empiricising of metaphysics, according to the same author, 
would ruin the very critical paradigm: no aspect of the existing, being ontic in its character (referring to Heidegger), could carry the burden of beingness - the upgrade of empirical (ontic) in their character elements into ontological worlds would drive philosophy into a dead end.

According to the first book of the Tetralogy, the metaphors «open valences» and «unlocking» supply pointers for thinking the transition from intentional specifics of transcendental synthesis to an intensional thought form and the relevant logical import explication of the transcendental synthesis activity - as a critically grounded regional attempt. In such a transition from intentionality to intensionality, it is of utmost importance that the synthesis possibility test is explicated as a generative mechanism toward an initially independent and free of thematic deductions, non-analyzed and undetermined objectness. «Open valences» is a metaphor of the virtual topos of thinking in a static sense, i.e. the emphasis is on its metaphysically clarified purity as a form and virtual being. Thus, the positing of the relevancy of form toward object oriented thinking supposes we would think the a priori as virtual being in itself, as topologisation of knowledge metaphysics. ${ }^{1}$ The definition of the a priori in static sense as metaphysically virtual guarantees the "valence openness" of thinking towards any possible experience (otherwise it would be, in Kanawrow's terms, a «block thinking», attached to a previously prepared ontology), and this openness is precisely where the «specifics of its possible relationising» lie. ${ }^{2}$ The dynamising of form as «unlocking its own usage» towards experience is protected against the temptations of uncritical fetishising of thinking and against the possible consequence of its uncontrolled association with material conditions or anthropological characteristics. ${ }^{3}$

In the second book of his Tetralogy, Kanawrow introduces as a central topic and defines the term «ontologems of spirituality» as «the initial, schematically deduced and focused ontological categorical units that are transcendentally deduced based on the virtualistically conceived metaphysics of knowledge»,

1 Kanawrow 2003: 188.

2 Ibid.: 186.

3 In the process of devirtualisation it is impossible for the metaphysical form, marked as «unlocking its own usage», to be extensially explicated, without a surplus (it would be possible, given an ontological presupposition, and given that the form is strictly and undeniably dependent on ontology). The unlocking of the form towards a phenomenally realizable schematisation (first level of transcendentalisation) supposes a possibility of reflexive movement of the form itself, of a «potentialisation of its potencies», having in mind the non-presupposed route towards schematisation of actual experience or, in other words, the potential channel multiplicity of the transition of a priori to a posteriori. 
which are «historically idealisational crystallisations of spiritual reality». ${ }^{4}$ Spirituality, from this point of view, is strictly related to the history of philosophy and to its conceptualizations as transformations of experience with significance in the human world, thus this experience turns into a spiritual one. The metaphor «crystallisations» plays an important role in relation to the introduction of intensionality as typisation of experience. In the same book, the transition from a priori to a posteriori is quite clearly explicated as a transition from intentionality (understood as a pure form of knowledge, unlocking its own usage) to intensional typics of regional (actual) human experience, which falls in the range of presumed open valences of thinking. ${ }^{5}$ It seems that, at this stage of the Tetralogy, the question of a methodologically reflected output and of a transformation of these typics in a transcendental aspect still remains. ${ }^{6}$

According to the third book, in relation to the aforementioned, the phenomena that replaced the classical Kantian transcendental scheme «have a simultaneous double 'nature': ideal (according to the a priori character of the forms of knowledge) and content-related (according to the object specifics of the concrete sphere of experience)». ${ }^{7}$ Having in mind that we stumble upon "unified intuitions" and/or «groups of empirical concepts» in the frame of a concrete regional experience, as Kanawrow notes in the second book of the Tetralogy, the transcendental synthesis «must somehow envision specified and concrete constellations of experience, in order to explicate them by

4 Kanawrow 2006: 60.

5 See: ibid.: 65

6 In my version of virtualism, I am attempting to raise the transcendental synthesis itself to the rang of a dynamised condition of actual experience, preserving imagination as a specific potentiality attached to the action-related side of the synthesis. If the content arrangements («crystallisations») are not thought as possible in a transcendental way, the virtiualistic construction will be left conceptually incomplete and in need of compensation through outer realia. There are two routes towards this: either through introduction of empirical (ontic) starting points of experiential content arrangement justification, which would ruin the foundations of the critical paradigm we start at, or through the introduction of an intellectual experience, different from the human one (similar to the Kantian «different understanding»), which has access to them in their content fullness and structure. However, the intellectual experience, as far as it is exclusively inherent to the human, should not be artificially connected with extrinsic ways of knowing that would introduce incoherence in the conceptual image of critical metaphysics and thus lead into the field of empty fantasizing. That's why the functual relativity of thinking to the figural synthesis turns out to be important in a methodological aspect. The transcendental as a «basic knowledge idealisation» (Kanawrow 2003: 212) somehow should include imagination as a basic concept theoretising it metaphysically - this is a solution which Kanawrow explicitly denies in the fourth book of the Tetralogy as unsuitable for the version of critical metaphysics he proposes.

7 Kanawrow 2011: 137. 
conceptualising them as necessary elements of the relevant critical ontologies»». ${ }^{8}$ This is precisely what necessitates this kind of proximity of the transcendental synthesis towards experiential constellations (or expressed in virtualistic metaphysical language - devirtualisation), which would somehow deformalise and «implant" the transcendental forms into the structure of a particularly organized, phenomenologised actual experience. In a similar sense, in turn, comes the clear explication of the virtualistic phenomena type that mediates the transcendentalising, respectively the phenomenologising of actual experience in the transition of a priori to a posteriori (which is expanded upon conceptually in the fourth book).

In the fourth book, the emphasis falls upon the so called by Kanawrow «second deduction» - the one of transcendental schemes. ${ }^{9}$ Again, it is realized in a transcendental way, but - and this is of crucial importance here-according to actual experience. At this key step of development of virtualistic metaphysics, the critical paradigm retains its transcendental character because the experience in question does not penetrate into the theorisation itself as its element, but is legitimised as an object of transcendental synthesis. However, the virtualistic solution for imagination in the same book is completely negative. ${ }^{10}$ It disappears from the critical construction, and the scheme, reinterpreted as a transcendental condition of experience, becomes a new type of mediator-phenomenon, multi-channelled in its potency; this is this author's route for transcendental phenomenologisation of the virtualistic type. (In the previous books of the Tetralogy, this is rather inferred, and, in fact, without clarity what we should do with actual experience as a pluralism of critical ontologies or (which means the same) of the content-related transcendental logics; without a clearly explicated principle of the multi-channelled mediator or a statement of concrete variants thereof.) This leads to a theoretically justified introduction of multi-directed transcendental schematism. The schemes are introduced as phenomena on the terrain of actual experience during its philosophical justification by the power of the categories of understanding. ${ }^{11}$

8 Kanawrow 2006: 46-47.

9 «The intentional dynamics of categories that come from the action-related 'nature' of the pure form of thinking and that is realized as transcendental synthesis during the a priori - a posteriori transition necessarily generate a deduction of schematism that mediates the transcendental transition itself and thus makes the work on the transcendental synthesis possible [...]»(Kanawrow 2015: 211).

10 «Virtualistic transcendentalism eliminates the imagination ability from the critical deduction of schemes, by seeking justification of their spontaneous characteristics in a pure conceptual aspect, of course, in the range of critique». (Ibid.: 204)

11 If we reinterpret the scheme as «(a new) structure whose functioning is immediately 
By «phenomenon» Valentin Kanawrow means the scheme as a transcendental condition of experience - condition, completely independent from experiential contents in its expansion as a devitalisation (transcendentalising) the route to its deduction is a priori and formal, in the field of experience it has a structural significance as a transcendental form of experience with cognitive and ontological functions. The logical functionalising of thinking receives a cognitive significance, but a critically postulate emphasis should be put on the fact that thinking remains independent of experience - the critical conceptuality has its own transcendental, virtualistic in its character, specifics.

The phenomenon does not have empirical characteristics: «it is a transcendental condition and a transcendental form of knowledge of objects, given in immediate experience. The phenomenon is what mediates and translates the rational format (categories) in a schematical way according to the cognitive elements of immediate experience». ${ }^{12}$ In his last book, Kanawrow marks as key phenomena types space-time, freedom and language (such could also be: religion, eros, artistry and many more). As for the possibility to use phenomena (which are no concepts!) to build a principally new cognitively metaphysical and transcendentally formal phenomenology, the author counts on their synthetic function, spontaneous genesis and covariability. This is the route of transcendental schematism in its virtualistic version that promises to turn into a powerful philosophical centre of attraction of future research efforts ad of significant results in the field of critical philosophy.

\section{REFERENCES}

KANAWROW, V. 2003. The Critical Metaphysics of Kant. An Attempt for Virtualistic Transcendentalism [in Bulgarian: Критическата метафизика на Кант. Опит за

directed towards the generation of the object concept» (Kanawrow 2003:303), the role of the transcendental scheme can conceive of the phenomenon as of «an action related manifestation of the synthesis itself» (ibid.). This move demands, in my opinion, that the «object specifics of the concrete sphere of experience" (a region) were acquired phenomenally (Kanawrow 2011:137), so that the scheme could be fully grasped in a dynamical aspect. Such an acquisition digresses seriously from the last variant of virtualism in the fourth book of the Tetralogy where «phenomenon» is the scheme as a transcendental condition of experience - a condition, totally independent from experiential content in the process of its expansion as devirtualisation (transcendentalisation). Personally, I don't think that the influence of actual experience cannot be captured and harnessed in a critically metaphysical order as a presence in the regional perspective of critical ontologies where the phenomenon would step upon the Kantian logical principle of variety in cooperation with the principles of unity and manifoldness, working in a dynamical interaction therewith. However, this is a different topic that requires a serious analysis in another study.

12 Cit. from personal correspondence: 2015. 
виртуалистки трансцендентализъм]. Veliko Tarnovo: Faber. 436 pages, abstract in German: pp. 389-415. ISBN 954-775-186-7.

___ 2006. Critical Ontologems of Spirituality. Veliko Tarnovo: Faber. [in Bulgarian: Критически онтологеми на духовността]. 398 pages, abstract in German: pp. 379-398. ISBN-10: 954-775-566-8; ISBN-13: 978-954-775-566-6.

___ 2011. Routes of Metaphysics. Kant and Heidegger. Sofia: Iztok-Zapad. [in Bulgarian: Пътища на метафизиката. Кант и Хайдегер]. 452 pages, abstract in German: pp. 434-451. ISBN 978-954-321-876-9.

, 2015. Routes of Transcendental Schematism. Sofia: Iztok-Zapad [in Bulgarian: Пътища на трансценденталния схематизъм]. 383 pages, abstract in German: pp. 365-383.ISBN 978-619-152-664-2

Kristyan Enchev is Associated Profesor of Philosophy at The Institute for the Study of Societies and Knowledge at the Bulgarian Academy of Science (ISSK-BAS) Sofia, Bulgaria.

Author's areas of interest:

transcendental logics, intensional logics, ontology, hermeneutics, critical meta-physics.

\section{Last Publications:}

«Play Aspects of the Transcendental Schematizations» [In Bulgarian: Игрови аспекти на трансценденталните схематизации] In: Philosophical Alternatives, Issue: 3/XXV/2016.

«The Double (Im)possibility of Metaphysical Form as a Virtualist Concept» [In Bulgarian: Двойната (не)възможност на метафизическата форма като виртуалистки концепт] In: Philosophical Alternatives Issue: 6/XXIV/2015.

E mail: chris.enchev@gmail.com 
